November 2016

\title{
Secrecy, Confidentiality and "Dirty Work": The Case of Public Relations
}

Sue Curry Jansen

Muhlenberg College

Follow this and additional works at: https://scholarworks.sjsu.edu/secrecyandsociety

Part of the American Studies Commons, History Commons, Political Science Commons, and the Public Affairs, Public Policy and Public Administration Commons

\section{Recommended Citation}

Curry Jansen, Sue. 2016. "Secrecy, Confidentiality and "Dirty Work": The Case of Public Relations." Secrecy and Society 1(1). https://doi.org/10.31979/2377-6188.2016.010105 https://scholarworks.sjsu.edu/secrecyandsociety/vol1/iss1/5

This Article is brought to you for free and open access by the School of Information at SJSU ScholarWorks. It has been accepted for inclusion in Secrecy and Society by an authorized administrator of SJSU ScholarWorks. For more information, please contact scholarworks@sjsu.edu.

\section{c) (i)}

This work is licensed under a Creative Commons Attribution 4.0 License. 


\section{Secrecy, Confidentiality and "Dirty Work": The Case of Public Relations}

\section{Keywords}

confidentiality, propaganda, public relations, secrecy, United States 


\section{Secrecy, Confidentiality and "Dirty Work": The Case of Public Relations $^{1}$}

\section{Sue Curry Jansen}

The prominent midcentury American sociologist Everett C. Hughes wrote a ground-breaking essay on the "dirty work'"that is part of every society. He begins his argument with a discussion of extreme cases - genocide in Nazi Germany, segregation maintained by lynching in the American South and apartheid in South Africa - but then asserts that these extremes point to "a phenomenon common to all societies":

\footnotetext{
Almost every group which has a specialized social function to perform is in some measure a secret society, with a body of rules developed and enforced by the members and with some power to save its members from outside punishment. $^{2}$
}

Viewing this enforcement power as a paradox of social bonding, Hughes maintains that, "A society without smaller, rule-making and disciplining powers would be no society at all." ${ }^{3}$ Hughes further contends that "good people" generally do not want to know what the enforcers who do a society's dirty work actually do. They look away, keep silent or repress knowledge that "would threaten the group's conception of itself" if subjected to open discussion. ${ }^{4}$ To break the silence is to betray the group. This is why whistleblowers - no matter 
how honorable their motives - are usually ostracized by their former compatriots and generally treated with suspicion even by those whose values and interests they are trying to defend.

The conspiracy of silence around societal dirty work allows history to be laundered and salutary myths to prevail. While democracies formally abhor government censorship and value transparency and publicity as essential to creating an informed citizenry, they also countenance various forms of censorship during wartime and other national emergencies. All of the advanced democracies also now routinely exercise forms of information control during peace time in the name of national security, broadly conceived - whether through regimens of classified information, intelligence agencies, surveillance or other stratagems.

Government agencies and businesses, which do society's dirty work, frequently develop jargons of evasion, which cover their efforts with a veneer of normalcy that renders them less visible. Bureaucracies institutionalize these euphemisms. Nowhere is this more apparent than in military and intelligent agencies. The U.S. military, for example, has developed an elaborate vocabulary of evasion to cover up the dirty work that is part of every war. Words such as "collateral damage" (civilian casualties), "soft targets" (cities), drone warfare (killing people by remote control) shield good people from 
having to acknowledge their complicity in morally contentious policies and actions.

While democracies have to stretch language and logic to paper over the dirty work that, according to Hughes' argument, is necessary to their survival, corporations operate under different rules. They are private enterprises, accountable primarily to their shareholders, while subject to various forms of government oversight and regulation, depending upon their locations and reach of their operations. Secrecy is, however, assumed to be an integral part of the corporate modus operandi. It is considered essential to protect trade secrets, negotiate deals and maintain competitive advantage. Like governments, corporations also have their disciplinarians and enforcers who do their dirty work.

This article briefly examines the origins and development of the dirty work that is done by some forms of corporate PR. It focuses primarily on the U.S., which invented corporate PR and exported it to the rest of the world where in recent decades its resources have been mobilized and deployed in the service of neoliberal globalization.

\section{Corporate Diplomacy}

In days of yore, corporate enforcers included police, strike breakers, Pinkerton agents, corrupt legislators and judges. The dirty work of trying to hold America together in its post-Civil War period was 
so dirty that it was referred to as "the Era of Good Stealings."

Corporate corruption of government had reached such extremes by 1888 that former Republican president Rutherford B. Hayes denounced "the vast wealth and power in the hands of the few and the unscrupulous who represent and control capital." Hayes maintained that, "Hundreds of laws of Congress and the state legislatures are in the interest of these men and against the interests of workingmen." Calling for the exposure and repeal of these laws, Hayes contended, "This is a government of the people, by the people, and for the people no longer. It is a government of corporations, by corporations, and for corporations." ${ }^{6}$

The Era of Good Stealings was followed by the Age of Reform, spearheaded by social activists and muckraking journalists who exposed corporate and government corruption. Anti-corruption, social welfare and corporate regulation legislation followed. The efficacy of these reforms has been disputed by some: for example, revisionist historian Gabriel Kolko maintained that the Progressive era (18901920) actually allowed major economic interests to gain control over politics rather than the federal government to gain regulatory control over business as other historians had widely assumed. For Kolko, the Age of Reform was a "triumph of conservatism."7 John Micklethwait and Adrian Wooldridge of The Economist, writing forty years later and 
from a very different perspective, draw a surprisingly similar conclusion. In their history of the modern corporation, The Company, they contend that during the Age of Reform the captains of industry "discovered that, with a little diplomacy, they could hang onto most of their fiefdoms." ${ }^{8}$

That diplomacy took multiple forms, eventually stimulating the growth of a whole range of related corporate service professions including legal services, tax accountancies, information resources, advertising and public relations - service providers that Nigel Thrift refers to as "the 'fixers' of capitalism. ${ }^{\prime 9}$ While most of these fields require codes of confidentiality to protect privacy and rules designed to discourage conflicts of interest among service providers, none of these fixers, except public relations, markets secrecy as its primary skill set. PR's essential corporate function is to influence public opinion through stealth communications. A familiar truism within the industry is that "the best PR is invisible PR." Once the props of PR initiatives are exposed, PR usually loses much of its efficacy.

Public relations monetized corporate diplomacy. It emerged during the Progressive era as a defensive response to attacks on corporations by government, religious leaders, muckrakers and the public at large. PR has been described by practitioners Trevor Morris and Simon Goldsworthy as the "weapon systems" of capitalism. ${ }^{10}$ The 
objective of corporate PR is to mediate the media. It inserts itself between the event and the report of the event, compromising or displacing the roles of reporters and editors by controlling the flow of information through press releases, strategic uses of language, staging events, promotional campaigns, third party endorsements and other techniques. In effect, it seeks to censor information at its source, and thereby dilute, pollute or deform the free flow of information upon which classic theories of democracy depend. Unlike advertising which, despite its use of manipulative techniques, has until fairly recently presented itself as a relatively open paid sales pitch, PR actively conceals its persuasive efforts from public view whenever possible. ${ }^{11}$ In doing so, it violates the basic norms of democratic discourse: "legibility and visibility." ${ }^{12}$

Governments and powerful people have, of course, always had agents and fixers; however the availability of a free press changes the dynamics of the dramaturgy of power. In the U.S., the rapid emergence of a free-wielding national media in the early twentieth century, facilitated by the development of the railroads and telegraph, transformed 'media relations' from an occasional, usually crisis-driven, corporate intervention into a routine practice that required fulltime attention. In effect, PR led the corporate counter-assault against the expansion of the democratic covenant that the Progressive movement 
heralded. It emerged to handle the backstage dirty work of corporate information control - a move that was roundly denounced at the time by such luminaries as John Dewey, Walter Lippmann, H.L. Mencken, Frank Cobb, future U.S. Senator Ernest Gruening and others.

While most PR people work quietly behind the scenes to advance their clients' interests, two figures emerged early as PR's titular founding fathers, Ivy Lee (1877-1934) and Edward L. Bernays (18911995). Both published books and sought the limelight to promote their businesses and ensure their legacies. Lee, a former journalist, had done publicity work for the railroads, but is best known for his efforts on behalf of the Rockefeller interests, the American Red Cross during World War I, and most infamously later in his career for I.F. Farben under the Nazi regime, which led to a congressional investigation of public relations. Bernays began his career as a theatrical promoter and became a member of the Committee on Public Information, the U.S.'s propaganda agency during World War I. After the war he decided to turn his propaganda talents - a term he used at the time without apologies - to the service of private industry. ${ }^{13}$

Bernays taught the first PR course and wrote one of the first textbooks on PR, which he saw as a profession superior to journalism because, in his view, journalists only report the news whereas public relations practitioners make the news. ${ }^{14}$ Bernays meant that quite 
literally in the full constructivist sense. Further, he contended that the objective of PR's constructivism is to "engineer the consent" of the public to elite conceptions of social reality. ${ }^{15}$ In his own memorable words:

The conscious and intelligent manipulation of the organized habits and opinions of the masses is an important element of democratic society. Those who manipulate this unseen mechanism of society constitute an invisible government which is the true ruling power of our country. ${ }^{16}$

Bernays is usually credited with creation of the "third party technique," whereby a seemingly independent credible source is secretly recruited to endorse a cause or product on behalf of the PR practitioner's client. This deceptive but widely used approach has spawned several related practices, including the use of front groups, astroturfing, push polls and various forms of online sockpuppetry.

In his 1928 book Propaganda, Bernays claimed that, "There are invisible rulers who control the destinies of millions. It is not generally realized to what extent the words and actions of our most influential public men are dictated by shrewd persons operating behind the scenes. ${ }^{17}$ As someone who knew what was not generally known, readers were presumably expected to conclude that Bernays was among the shrewdest of the shrewd persons operating behind the scenes. 
Both PR and publics have come a long way since the days of Lee, Bernays and the other PR pioneers. Public relations techniques have become more sophisticated and extend far beyond corporate venues. Governments and non-governmental organizations (NGOs), including charities, now rely extensively on PR. Indeed public relations services may now be indispensable for organizations seeking to break through the noise of the twenty-first century information glut. The kind of corporate PR dirty work described here represents a small but particularly virulent form of public relations: experts estimate about $30 \%$, with most of the rest of the field devoted primarily to publicity and commercial promotions. ${ }^{18}$

The public has also become more discerning. Most people in media saturated cultures realize that opinion management is a pervasive presence in their lives. The much vaunted search for "authenticity," especially among young people today, suggests that the public resents that presence. Cultural critics certainly do. They claim "spin" erodes the trust in public institutions upon which democracy depends, corrupts language, cultivates cynicism, and creates a climate in which what satirist Stephen Colbert calls "truthiness" prevails - a condition whereby what intuitively "feels true" is treated as true despite logical and empirical evidence to the contrary. 
Yet, few people outside of the industry can name a single public relations firm. The industry's relative invisibility remains intact. Instead, "the media," PR's proxy, partner and primary purveyor, has become the visible target of the public's resentment of the perceived inauthenticity of public communications. Ironically, even political candidates, who have the full resources of PR techniques, campaign consultants and media manipulation expertise scripting them, can gain political capital by attacking "the media."

Public opinion polls show a precipitous decline over the past four decades in the public's confidence in media institutions, even though people are consuming more media than ever. ${ }^{19}$ Media may deserve public distrust, but killing willing messengers does not get to the source of the problem: the "shrewd persons operating behind the scenes."

With some notable exceptions, critical scholars have largely ignored PR on the assumption that "there is no there there": no substance worth excavating. ${ }^{20}$ The phrase, "It's just PR" expresses this intellectual indifference, implying that PR is just so much vacuous hot air, easily seen through and without significant consequences. This attitude does, however, appear to be waning as the role of public relations in climate denial and in attempts to undermine science and scientists more generally receives increasing publicity, some of it 
originating from dissident PR practitioners. ${ }^{21}$ The role of PR in drumming up public support for the 1991 and 2003 U.S. led wars in Iraq has also been retroactively exposed.

Public Relations played a central role in the long campaign, initiated by the DuPont brothers, to re-sell American capitalism to the public after it reached its nadir in the U.S. during the Great Depression - a campaign that successfully conflated capitalism with democracy. ${ }^{22}$ Financial PR was also much in demand in the wake of the 2008-2009 global financial crises. The field has also been implicated at multiple levels in generating ideological rationales justifying the escalating social inequalities in affluent Western nations since the 1970 s.

\section{Neolberalism and PR Dirty Work}

Yet, the crucial role PR plays under neoliberalism still remains under-appreciated and under-researched. According to Richard Edelman, CEO of Edelman Public Relations, which bills itself as the world's largest independent PR firm with offices in 65 cities globally and affiliates in more than 35 additional cities, "We used to be the tail wagging the dog," but now, PR is "the organizing principle" behind many business decisions. ${ }^{23}$ Today, he says, PR functions as "the cutting edge of corporate power. ${ }^{24}$ It is also frequently a cutting edge of state power and of neoliberal mergers of corporate and state power. Outsourcing of government services to private contractors has 
accelerated so extensively that some researchers maintain that the fields of public relations and international relations are converging. ${ }^{25}$ Indeed, former U.S. Ambassador Anthony Quainton sardonically observed that "diplomacy is no longer the function of diplomats." 26 Although PR has been thoroughly globalized with China and Russian among the fastest growing markets, U.S. public relations firms still dominate international PR with 15 of the 20 largest global firms. Many of those firms have been called out by the watchdog group Corporate Europe Observatory's (CEO) report Spin Doctors to Autocrats (2015). ${ }^{27}$ While the report focuses primarily on European PR firms that "whitewash repressive regimes," American companies are also prominently represented among the PR firms that serve regimes that the European Union considers to be in violation of human rights or accused of war crimes. CEO reports on 18 cases, which it contends "can only be considered the tip of a larger iceberg" because "the most controversial the client, the less likely it is to have been uncovered by our research. ${ }^{\prime 28}$ The U.S. based Center for Public Integrity (CPI) exposed more of the iceberg by compiling a list of PR and lobbying firms that "give human rights abusers a friendly face." In 2015, the CPI reported that U.S. firms received $\$ 168$ million in fees since 2010 from "50 countries with the worst human rights violation records." 29 
According to some analysts, under neoliberalism, PR has become "war by other means." John Feffer contends that "The PR race is not that different from the arms race." He points out that an increase in spending on one side triggers an increase by its adversaries with "firms hoping that the spin they set in motion will, through the alchemy of the media, turn into 'facts' in an editorial, or an op-ed, or even a reporter's dispatch. ${ }^{\prime \prime 30}$

If the PR arms races actually culminated in war by other means with money spilling out of state coffers instead of blood spilling out of veins, this would be a positive development. But too often PR wars cover up human rights abuses, glorify tyrants, justify exploitive labor practices, co-opt NGOs and undercut campaigns for social justice. And, of course, information wars are frequently preludes to, rather than substitutes for, actual wars.

Corporate mercenaries defending authoritarian regimes do, however, add a chilling literal twist to the description of public relations as one of "the weapon systems" of capitalism. ${ }^{31}$ The firms catering to autocrats are not sketchy, pop-up, boutique operations. They are mainstream firms, including some of the largest firms in the world. Six of the top ten global firms made the hall of shame in CEO's Spin Doctors to the Autocrats report, including Weber Shandwick, 
Ketchum, Burson-Marstellar, Hill \& Knowlton Strategies, Havas PR and to a lesser degree, Edelman. ${ }^{32}$

Those who examine the role of international PR under neoliberalism will find that there are many toxic secrets to be excavated and subjected to critical illumination. If the best PR is invisible PR, then rendering the industry's dirtiest work visible, where it may lose some of its efficacy, does a service to human rights as well as to truth and perhaps even to the much vaunted but elusive ideal of authenticity. 
${ }^{1}$ This article draws on the research for my forthcoming book, Stealth Communications: The Spectacular Rise of Public Relations. Cambridge: Polity, 2016.

${ }^{2}$ Everett C. Hughes, "Good People and Dirty Work," Social Problems 10, 1 (1962): 10-11.

${ }^{3}$ Hughes, 11.

${ }^{4}$ Hughes, 6.

${ }^{5}$ Mark Walgren Summers, The Era of Good Stealings. New York: Oxford University Press, 1993.

${ }^{6}$ Rutherford B. Hayes, Diary and Letters of Rutherford B. Hayes. Edited by Charles Richard Williams. Vol. 4, p. 374, Diary entry for Mar. 11, 1888. Whitefish, MT.: Kessinger Publishing, 2007, 374.

7 Gabriel Kolko, The Triumph of Conservatism. New York: The Free Press, 1963.

${ }^{8}$ John Micklethwait and Adrian Wooldridge, The Company. New York: The Modern Library, 2005, 74.

${ }^{9}$ Nigel Thrift, "The Urban Geography of International Commercial Capital." In Global Restructuring and Territorial Development edited by Jeffrey Henderson and Manuel Castells. London: Sage, 1987, pp. 207-208. Advertising is, of course, much older, but it expanded and changed dramatically in the early twentieth century from being largely informational to using social psychological appeals promoting consumption. See Stuart Ewen, Captains of Consciousness: Advertising and the Social Roots of the Consumer Culture. New York: McGraw-Hill, 1976.

${ }^{10}$ Trevor Morris and Simon Goldsworthy, $P R-A$ Persuasive Industry, London: Palgrave, 2008, 177.

${ }^{11}$ According to Michael Serazio, advertising today is becoming more like PR in covering its tracks because of growing consumer skepticism and resistance. Serazio, Your Ad Here: The Cool Sell of Guerrilla Marketing. New York: New York University Press, 2013. 'Native advertising,' in which paid promotional material is presented as editorial or news features, is part of this trend.

${ }^{12}$ Richard Sennet, Authority. New York: Knopf, 1980, 189.

13 Edward L. Bernays, Biography of an Idea: Memoirs of Public Relations Counsel Edward L. Bernays. New York: Simon and Schuster, 1965.

${ }^{14}$ Edward L. Bernays, Propaganda. Brooklyn, NY: IG Publishing, Brooklyn, NY, [1928], 2008.

${ }^{15}$ Edward L. Bernays, The Engineering of Consent. Norman: University of Oklahoma Press, 1955.

16 Bernays, Propaganda, 37.

17 Bernays, Propaganda, 61.

${ }^{18}$ Morris and Goldsworthy, $P R-A$ Persuasive Industry.

${ }^{19}$ Andrew Dugan, "Americans' Confidence in News Media Remains Low: Across Newspapers, TV and Internet, Confidence No Higher than 22\%." Gallup Politics, June 19, 2004, http://www.gallup.com

20 Some of the notable critical exceptions are Alex Carey's Taking the Risk Out of Democracy (1995), Aeron Davis' Public Relations Democracy (2002) and Promotional Cultures (2013), Stuart 
Ewen's PR! A Social History of Spin (1996), several volumes by Sharon Beder, beginning with Global Spin: The Corporate Assault on Environmentalism (1997), Roland Marchand's Creating the Corporate Soul (1998), the collaborative works of David Miller and William Dineen, including $A$ Century of Spin: How Public Relations became the Cutting Edge of Corporate Power (2008) and Kevin Moloney, (2000) Rethinking Public Relations: The Spin and Substance (2000). The work of John Stauber and Sheldon Rampton also fit this profile, including their books, especially Toxic Sludge is Good for You (2002) as well as their contributions to Media and Democracy's PR Watch website (from 1995 to 2009). Miller and Dineen are part of a larger U.K. group that maintains a similar website, Spinwatch, which, "investigates the way that the public relations (PR) industry and corporate and government propaganda distort public debate and undermine democracy." An outlier in the critical realm is conservative Marvin N. Olasky's Corporate Public Relations: A New Historical View (1987). Finally Jurgen Habermas included an important critique of PR in the final chapter of his opus, The Structural Transformation of the Public Sphere (1962).

${ }^{21}$ See for example James Hoggan, Climate Cover-Up: The Crusade to Deny Global Warming (2009) and Robert Phillips, Trust Me, PR is Dead (2015).

${ }^{22}$ Elizabeth Fones-Wolf, Selling Free Enterprise. Champaign, IL: University of Illinois Press, 1994.

${ }^{23}$ The Economist quotes Richard Edelman, "Public Relations in the Recession: Good News," January 14, 2010 at http://www.economist.com.

24 William Dinan and David Miller, Thinker, Faker, Spinner, Spy: Corporate PR and Assault on Democracy. Pluto Press, London, 2008, 1.

${ }^{25}$ Benno Signitzer \& W. Timothy Coombs "Public Relations and Public Diplomacy: Conceptual Convergences," Public Relations Review 18 (1992): 137-147; and Peter Van Ham, "Branding Territory: Inside the Wonderful Worlds of PR and IR Theory". Millennium: Journal of International Studies 32 (2002): 249-269.

${ }^{26}$ Quintin quoted by Allison Stanger (2009) One Nation Under Contract. New Haven Yale University Press, 2009: 63.

${ }^{27}$ Corporate Europe Observatory, Spin Doctors to Autocrats: How European PR Firms Whitewash Repressive Regimes, 2015 at http://www.corporateeurope.org

${ }^{28}$ Corporate Europe Observatory, Spin Doctors to Autocrats, 4.

${ }^{29}$ Center for Public Integrity, "U.S Lobbying/PR Firms Give Human Rights Abusers a Friendly Face," December 17, 2015 at http://www.publicintegrity.com. Also see the Center's, "Rape, Murder, Famine -and $\$ 2.1$ million for K Street PR," July 14, 2016.

30 John Feffer (2009) "Global Spin Doctors," Foreign Policy in Focus 4 (accessed September 22, 2016) http://fpif.org/global_spin_doctors/

31 Morris \& Goldsworthy, $P R-A$ Persuasive Industry, 177.

${ }^{32}$ Rankings according to the 2015 Holmes Report, the trade publication that tracks international PR. 